\title{
The Neurotensin Gene Is a Downstream Target for Ras Activation
}

\author{
B. Mark Evers, Zhichao Zhou, Paul Celano, ${ }^{\star}$ and Jing Li \\ Department of Surgery, The University of Texas Medical Branch, Galveston, Texas 77555; and *The Oncology Center, Johns Hopkins \\ School of Medicine, Baltimore, Maryland 21287
}

\section{Abstract}

Ras regulates novel patterns of gene expression and the differentiation of various eukaryotic cell types. Stable transfection of Ha-ras into the human colon cancer line $\mathrm{CaCo} 2$ results in the morphologic differentiation to a small bowel phenotype. The purpose of our study was to determine whether the Ras regulatory pathway plays a role in the expression of the neurotensin gene (NT/N), a terminally differentiated endocrine product specifically localized in the gastrointestinal tract to the adult small bowel. We found that $\mathrm{CaCo2}-$ ras cells, but not parental $\mathrm{CaCo2}$, express high levels of the human NT/N gene and, moreover, that this increase in gene expression is regulated at the level of transcription. Transfection experiments using NT/N-CAT mutation constructs identify the proximal 200 bp of NT/N flanking sequence as sufficient for maximal Ras-mediated NT/N reporter gene induction. Furthermore, a proximal AP-1/ CRE motif is crucial for this Ras-mediated NT/N activation. Wild-type Ha-ras induces NT/N gene expression, albeit at lower levels than activated Ras; a dominant-negative Raf blocks this NT/N induction, suggesting that Raf lies downstream of Ras in this pathway. In addition, postconfluent cultures of $\mathrm{CaCo} 2$ cells, which are differentiated to a small bowel phenotype, express the NT/N gene by $6 \mathrm{~d}$ after reaching confluency; this increase of NT/N expression is associated with concomitant increases of cellular $\mathbf{p 2}^{\text {ras }}$ protein. We conclude that Ras (both wild-type and activated) enhances expression of the NT/N gene in the gut-derived CaCo2 cell line, suggesting an important role for the Ras signaling pathway in NT/N gene transcription. Our results underscore the possibility that tissue-specific genes (such as NT/N) expressed in distinct subpopulations of the gut may be subject to Ras regulation. Finally, we speculate that the $\mathrm{NT} / \mathrm{N}$ gene and the $\mathrm{CaCo} 2$ and $\mathrm{CaCo2}-$ ras cell systems will provide unique models to further define the cellular mechanisms leading to mammalian intestinal differentiation. $(J$. Clin. Invest. 1995. 95:2822-2830.) Key words: differentiation • small bowel • CaCo2 cells • endocrine gene expression

This study was presented in part in a Research Forum at the Annual Meeting of the American Gastroenterologic Association held in New Orleans, LA on 17 May 1994 and was published in abstract form (1994. Gastroenterology. 106:606a).

Address correspondence to B. Mark Evers, MD, Department of Surgery, The University of Texas Medical Branch, 301 University Blvd., Galveston, TX 77555-0533. Phone: 409-772-5254; FAX: 409-772-6368.

Received for publication 29. August 1994 and in revised form 6 February 1995.

J. Clin. Invest.

(C) The American Society for Clinical Investigation, Inc.

0021-9738/95/06/2822/09 \$2.00

Volume 95, June 1995, 2822-2830

\section{Introduction}

Members of the ras gene family encode small guanine nucleotide-binding proteins localized to the inner surface of the plasma membrane that play central roles in the signal transduction pathways in mammalian cells (1-3). Activated GTP-Ras associates with the c-Raf protein kinase and contributes to its activation; Raf has been shown to phosphorylate and activate MAPKK (mitogen-activated protein kinase kinase), also known as MEK, which in turn phosphorylates and activates mitogen-activated protein kinases (also described as extracellular signal-regulated kinases (4-9). The extracellular signal-related kinases translocate to the nucleus and preferentially stimulate the activity of nuclear transcription factors (e.g., the activator protein-1 [AP$1]^{1}$ protein c-Jun) $(10-15)$. This cellular cascade culminates eventually in the malignant transformation or differentiation of a number of eukaryotic cell types $(11,12)$. The transforming property of $\mathrm{v}$-Ha-ras and the ability of this gene to immortalize various cell types are well established $(13,16)$; however, much less is known about the role of Ras in normal cellular differentiation and development.

Oncogenic Ha-ras induces neuroendocrine differentiation in rat pheochromocytoma (PC12) cells (17-20) and medullary thyroid carcinoma cells (21), and results in the differentiation of 3T3-L1 fibroblasts to adipocytes (22). This Ras-mediated response appears to be highly tissue specific, because Thorburn et al. (23) demonstrated that activated Ras induces a differentiated phenotype in cardiac muscle cells, but inhibits differentiation in skeletal muscle. In addition, stable transfection of the Ha-ras oncogene leads to the morphologic differentiation of the human colon cancer line $\mathrm{CaCo} 2$ into a small bowel phenotype as characterized by a decreased proliferative capacity and an increased expression of the brush border hydrolase genes sucrase-isomaltase and alkaline phosphatase, enzymes normally produced in the terminally differentiated enterocytes of the gut (24). These findings suggest that Ras may play a dominant role in gut differentiation and the eventual expression of various terminally differentiated products (e.g., gut hormones). Further evidence to support this hypothesis is provided by the finding of low levels of $\mathrm{p} 21^{\text {ras }}$ in the undifferentiated, rapidly proliferating crypt cells but increased expression of endogenous p21 ${ }^{\text {ras }}$ in the most mature cells of the gastrointestinal (GI) mucosa such as villus tip cells and endocrine cells (25).

Neurotensin (NT), an important regulatory hormone of the gut, is localized in the GI tract to specialized enteroendocrine cells ( $\mathrm{N}$ cells) of the adult small bowel (for review see reference 26). NT facilitates translocation of fatty acids in the proximal small bowel (27) and affects numerous aspects of GI function

1. Abbreviations used in this paper: AP-1, activator protein-1; ATF, activating transcription factor; CAT, chloramphenicol acetyl transferase; CRE, cAMP response element; GAPDH, glyceraldehyde-3-phosphate dehydrogenase; GI, gastrointestinal tract; NT, neurotensin; NT/N, neurotensin/neuromedin. 
including secretion, motility, and gut mucosal growth (28-36). Expression of the gene encoding NT and the structurally related hexapeptide neuromedin $\mathrm{N}$ (designated NT/N) is developmentally regulated in the gut of both rat and human in a distinctive temporal- and spatial-specific distribution $(37,38)$. NT/N expression is initially low in the fetus but rapidly increases after birth to assume the distinctive adult topographical distribution of increasing NT/N expression along the longitudinal axis of the small bowel. Using isolated gut segments from the rat implanted as xenografts in athymic nude mice, we recently demonstrated that the strict temporal- and spatial-specific pattern of NT/N expression is not affected by either location or luminal contents, thus suggesting an intrinsic program of NT/N gene expression (39). In the human colon, NT/N is transiently expressed during a developmental stage (midgestation) that is characterized by morphologic and functional similarity to the small bowel $(40,41)$; however, expression of NT/N is not apparent in the colon of the newborn or the adult (37). Taken together, these studies identify the NT/N gene as an important endocrine model to better delineate the complex mechanisms leading to differentiation of the gut to either a small bowel or colonic phenotype.

The purpose of this study was to determine whether the Ras regulatory pathway plays a role in the expression of NT/N, a gut hormone specifically produced in terminally differentiated endocrine cells of the adult small bowel. Our findings demonstrate that either stable or transient transfection of activated Ha-ras into the $\mathrm{CaCo} 2$ cell line is associated with constitutive activation of NT/N gene expression, which appears to be mediated by an induction of NT/N gene transcription; a proximal AP-1/CRE promoter element of the NT/N gene is crucial for this activation. In addition, cotransfection of wild-type Ha-ras results in a modest increase in NT/N promoter activity; this induction was blocked by a plasmid encoding a dominant-negative Raf kinase. Furthermore, in the $\mathrm{CaCo} 2$ cell system, we are able to demonstrate concomitant increases of $\mathrm{p} 21^{\text {ras }}$ protein and NT/N gene expression in postconfluent (differentiated) cultures. Collectively, these studies support an important role for Ras in the expression of the NT/N gene in small bowel-differentiated $\mathrm{CaCo} 2$ cells. Finally, this model system provides a useful paradigm for the further elucidation of the cellular mechanisms regulating mammalian intestinal differentiation.

\section{Methods}

Materials. Restriction, ligation, and other DNA-modifying enzymes were purchased from Promega Corp. (Madison, WI) or Stratagene Inc. (La Jolla, CA). Oligo(dT) cellulose (type III) was obtained from Collaborative Research, Inc. (Bedford, MA) and radioactive compounds were obtained from Du Pont - New England Nuclear (Boston, MA). Tissue culture media and reagents were obtained from GIBCO BRL (Grand Island, NY). All other reagents were of molecular biology grade and were either obtained from Sigma Chemical Co. (St. Louis, MO) or Amresco (Solon, $\mathrm{OH}$ ). Thin-layer chromatography (TLC) plates were purchased from Whatman Labsales (Hillsboro, OR), EN ${ }^{3}$ HANCE spray from Du Pont (Boston, MA), and autoradiography film from Kodak (Rochester, NY). Nitrocellulose filters for Northern blots were from Sartorius Corp. (Göttingen, Germany) and Immobilon P membranes for Western blots were from Millipore Corp. (Bedford, MA). RNase protection experiments were performed using the RPA-II kit from Ambion, Inc. (Austin, TX). To determine the relative size of the protection products, ${ }^{32} \mathrm{P}$-labeled Hinfl-digested $\phi$ X174 DNA fragments (Promega) and RNA markers (Ambion) transcribed with T7 RNA polymerase were run in parallel lanes. The constitutively expressed human glyceralde- hyde-3-phosphate dehydrogenase (GAPDH) gene was obtained from Ambion and used to ensure integrity of the RNA samples analyzed by both Northern blot and RNase protection. A rat anti-Ras monoclonal antibody (no. 259) that recognizes antigenic determinants common to $\mathrm{Ha}-, \mathrm{Ki}-$, and $\mathrm{N}$-ras p21s was purchased from Santa Cruz (Santa Cruz, CA). The enhanced chemiluminescence system for Western immunoblot analysis was from Amersham Corp. (Arlington Heights, IL).

Cell culture. The human colon cancer cell line $\mathrm{CaCo} 2$ is maintained in modified Eagle's medium (MEM) supplemented with $15 \%$ (vol/vol) fetal calf serum (FCS). The CaCo2-ras cell line was derived from the native $\mathrm{CaCo} 2$ cell line by transfection of the provirus vector pZIPNeo$\mathrm{v}-\mathrm{Ha}$-ras containing a val ${ }^{12}$ mutation and has been previously described and characterized (24). CaCo2-ras cells are cultured in MEM with $15 \%$ FCS and the antibiotic G418 $(400 \mu \mathrm{g} / \mathrm{ml})$. All cells are maintained in a humidified atmosphere of $95 \%$ air and $5 \% \mathrm{CO}_{2}$ at $37^{\circ} \mathrm{C}$.

RNA extraction, Northern blot analysis, ribonuclease (RNase) protection assay. Cells were harvested, and RNA was obtained by the method of Schwab et al. (42). Polyadenylated (Poly[A $]^{+}$) RNA was selected from all samples by oligo(dT) cellulose column chromatography, and the final RNA concentration was quantified spectrophotometrically by the absorbance at $260 \mathrm{~nm}$. For Northern blot analysis, poly(A) ${ }^{+}$ RNA $(10 \mu \mathrm{g})$ was electrophoresed in $1.2 \%$ agarose-formaldehyde gels, transferred to nitrocellulose, and hybridized with an RNA probe (pHNT EO.9) containing 806 bp of the human NT/N gene subcloned into the EcoRI site of a pGEM4 vector (43). Hybridization and washing conditions were described previously $(44,45)$. Blots were stripped and reprobed with the constitutively expressed GAPDH gene to ensure intact RNA samples.

For RNase protection assays, poly(A) ${ }^{+}$RNA from nontransfected $\mathrm{CaCo} 2$ and $\mathrm{CaCo} 2$-ras was hybridized with the human NT/N cRNA probe (pHNT EO.9). To ensure proper transcriptional initiation and confirm findings by functional promoter analyses, $\mathrm{CaCo} 2$ cells transiently transfected with rat NT/N $5^{\prime}$ deletion vectors (with or without the ras expression vector) were harvested $48 \mathrm{~h}$ after transfection. Hybrid rat NT/N-CAT mRNA transcripts were detected using an RNA probe (pG4-20) generated by subcloning a 364-bp fragment containing rat NT/ $\mathrm{N}$ sequences between -43 and +56 and the first 253 nucleotides of the CAT gene into EcoRI/BamHI sites of a pGEM4 vector, and the antisense fragment was transcribed with SP6 RNA polymerase after linearizing with BamHI. To ensure intact RNA samples and assess any loading differences, separate RNase protection assays were performed using the human GAPDH probe hybridized with duplicate RNA samples.

RNase protection experiments were carried out using the RPA-II kit according to the instructions of the supplier. Briefly, RNA $(5 \mu \mathrm{g})$ was hybridized with the ${ }^{32} \mathrm{P}$-labeled antisense RNA probes overnight at $55^{\circ} \mathrm{C}$, followed by RNase digestion for $30 \mathrm{~min}$ at room temperature. RNA pellets were dried briefly, resuspended in $8 \mu \mathrm{l}$ of a formamide-loading buffer and RNase-resistant fragments separated on a $5 \%$ polyacrylamide- $8 \mathrm{M}$ urea gel and visualized by autoradiography.

Isolation of nuclei and run-on assay. To determine whether ras alters the transcription rate of $\mathrm{NT} / \mathrm{N}$ in $\mathrm{CaCo} 2$ cells, nuclear run-on assays were performed (46). Approximately $3 \times 10^{7} \mathrm{CaCo} 2-$ ras and $\mathrm{CaCo} 2$ cells were washed with phosphate-buffered saline (PBS) and scraped into ice-cold hypotonic lysis buffer (20 mM Tris- $\mathrm{HCl}$ [pH 7.4], $10 \mathrm{mM} \mathrm{NaCl}, 3 \mathrm{mM} \mathrm{MgCl}$ ) to which $0.5 \%$ Nonidet $\mathrm{P}-40$ was later added. Cells were broken with $20-30$ strokes in a Dounce homogenizer (B pestle). After centrifugation, nuclear pellets were resuspended in cold nuclear storage buffer ( $50 \mathrm{mM}$ Tris- $\mathrm{HCl}$ [pH 7.5], $0.1 \mathrm{mM}$ EDTA, 5 $\mathrm{mM} \mathrm{MgCl}$, and $40 \%$ glycerol) and immediately frozen.

In vitro run-on transcription was carried out using $\sim 10^{7}$ nuclei at $30^{\circ} \mathrm{C}$ for $45 \mathrm{~min}$ in a solution of $(\mathrm{mM}) 10$ Tris- $\mathrm{HCl}, \mathrm{pH} 8.0,5 \mathrm{MgCl}_{2}$, 0.5 each of ATP, CTP, GTP, $0.3 \mathrm{M} \mathrm{KCl}$ and $200 \mu \mathrm{Ci}$ of $\left[\alpha^{-}{ }^{32} \mathrm{P}\right] \mathrm{UTP}$ $(3,000 \mathrm{Ci} / \mathrm{mmol})$ with $40 \mathrm{U}$ RNasin. The transcription reaction was stopped with RNase-free DNase and proteinase $K$ and extracted with phenol:chloroform followed by precipitation of RNA in trichloroacetic acid. $5 \mu \mathrm{g}$ of either the plasmid containing the linearized human NT/N cDNA in the vector PGEM4 (43), the pGEM4 vector without insert, the plasmid containing $\beta$-actin cDNA (47), or the plasmid containing cyclophilin (48) was denatured by heating to $100^{\circ} \mathrm{C}$ for $2 \min$ in $0.1 \mathrm{~N}$ 


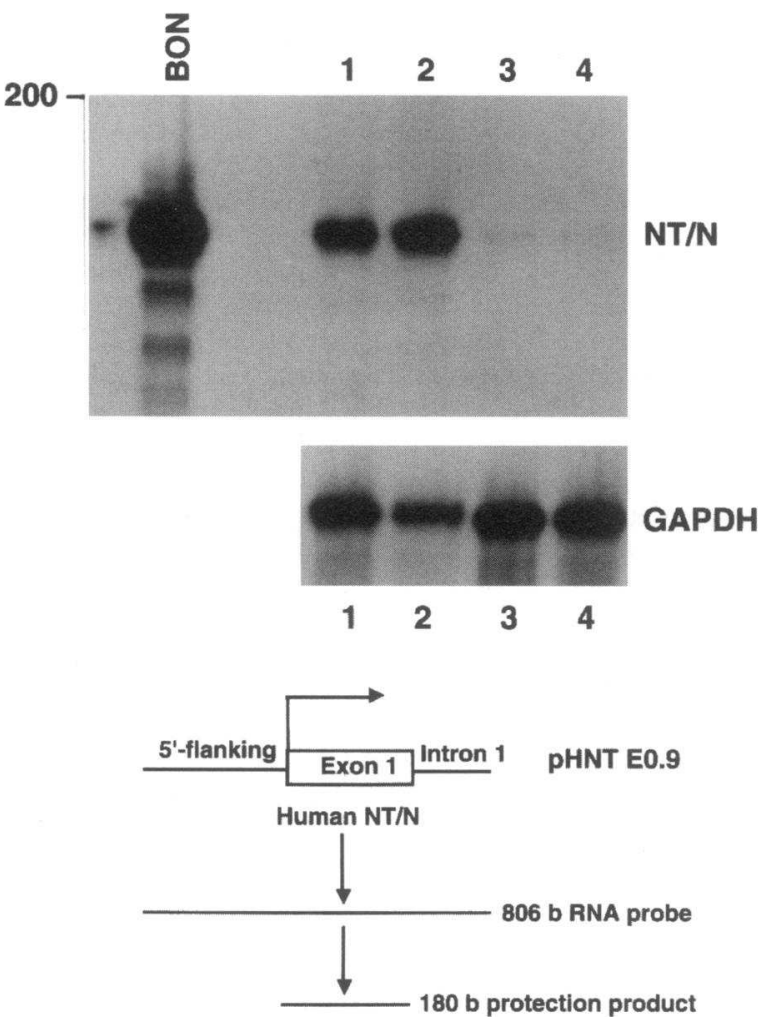

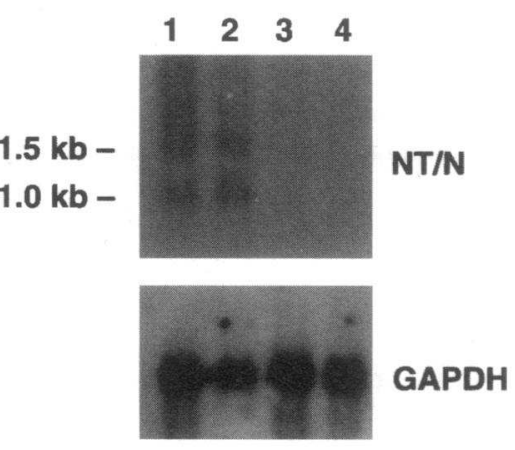

Figure 1. NT/N gene expression in $\mathrm{CaCo2}$-ras cells. $(A) \mathrm{RNase}$ protection analysis. ${ }^{32} \mathrm{P}$-labeled human NT/N RNA probe (pHNT EO.9; shown in schematic diagram) was hybridized with $10 \mu \mathrm{g}$ poly(A) ${ }^{+}$RNA from CaCo2-ras (lanes 1 and 2) and parental $\mathrm{CaCo} 2$ cells (lanes 3 and 4). BON cell RNA $(2.5 \mu \mathrm{g})$ was used as a positive control. RNA from BON and $\mathrm{CaCo} 2$-ras demonstrate an expected protection product of 180 bases, consistent with exon 1 of the human NT/N gene. To ensure intact RNA samples, a separate RNase protection assay was performed using human GAPDH as a probe. $(B)$ Northern blot analysis. RNA samples from $\mathrm{CaCo} 2-$ ras (lanes 1 and 2) and $\mathrm{CaCo} 2$ cells (lanes 3 and 4 ) were analyzed by Northern blot. CaCo2-ras cells demonstrate NT/N transcripts of the correct sizes ( 1.5 and $1.0 \mathrm{~kb})$. The blot was stripped and reprobed with GAPDH to confirm equal loading and intact RNA. sodium hydroxide and applied to nitrocellulose with a slot-blot manifold. A total of $10^{7} \mathrm{cpm} / \mathrm{ml}$ elongated nascent RNA from either CaCo2-ras or $\mathrm{CaCo} 2$ was hybridized for $48 \mathrm{~h}$ at $65^{\circ} \mathrm{C}$ to the denatured cDNAs immobilized on nitrocellulose. The filters were washed with $2 \times$ SSC ( $1 \times$ SSC $=0.15 \mathrm{M}$ sodium chloride and $0.015 \mathrm{M}$ sodium citrate) at $65^{\circ} \mathrm{C}$ for $1 \mathrm{~h}$. Filters were next incubated with $8 \mathrm{ml}$ RNase-A $(10 \mu \mathrm{g} /$ $\mathrm{ml}$ ) in $2 \times \mathrm{SSC}$ for $30 \mathrm{~min}$ at $37^{\circ} \mathrm{C}$ and then for $1 \mathrm{~h}$ in $2 \times \mathrm{SSC}$, and then dried and exposed to $\mathrm{X}$-ray film.

Transient transfection, chloramphenicol acetyltransferase (CAT) and $\beta$-galactosidase assays. Rat NT/N 5'-deletion and linker scanning $(-189 /-182$ and $-52 /-43)$ reporter constructs have been described previously (49) and provided by Dr. Paul Dobner (University of Massachusetts, Worcester, MA). The expression plasmids, pZIP-Ras(WT) and pZIP-Ras(61L), which encode wild-type (normal) and an activated form (leu 61) of human Ha-ras, respectively, were provided by Dr. Channing J. Der (University of North Carolina, Chapel Hill, NC) $(50,51)$. Constructs encoding a dominant-negative form of the c-Raf-1 protein (RafC4) and a mutant of Raf-C4 (Raf-C4pm17), which is no longer dominant-negative, were provided by Dr. Ulf Rapp (National Cancer Institute, Frederick, MD) (52). All plasmids were prepared by alkaline lysis followed by two successive bandings on cesium chloride density gradients using standard methods (53).

$1 \mathrm{~d}$ before transfection, cells were seeded at $2 \times 10^{6}$ in $100-\mathrm{mm}$ diameter culture dishes. Cells were refed $2-3 \mathrm{~h}$ before DNA transfection by the calcium phosphate coprecipitation technique $(54,55)$. To control for differences in transfection efficiency, cells were cotransfected with $5 \mu \mathrm{g}$ of the $\beta$-galactosidase plasmid $\mathrm{pCH} 110$ (56). In the assays in which the NT/N-CAT reporter constructs were transfected with various amounts of the $61 \mathrm{~L}$ ras expression construct, the amount of DNA in each transfection was held constant by adding vector DNA (pGEM4). The medium was removed $4 \mathrm{~h}$ later and cells were treated for 2 min with $15 \%$ (vol/vol) glycerol in PBS, washed twice with Hepes-buffered saline, and refed. Cells were harvested $48 \mathrm{~h}$ after the addition of DNA.

Cell extracts were prepared by freeze-thawing the transfected cells three times in $100 \mu \mathrm{l}$ of $0.25 \mathrm{M}$ Tris- $\mathrm{HCl}(\mathrm{pH} 7.5)$ and centrifugation for $10 \mathrm{~min}$ at $4^{\circ} \mathrm{C}$. Protein concentrations were determined by the method of Bradford (57). CAT activity in the cell extracts was assayed as described by Gorman et al. (55) with acetyl coenzyme A and $\left[{ }^{14} \mathrm{C}\right]-$ chloramphenicol. The reaction products were separated by thin-layer autoradiography. Acetylated reactions were quantified by liquid scintillation counting of the excised TLC spots. $\beta$-Galactosidase assays were carried out as follows: $20 \mu \mathrm{l}$ supernatant was added to $0.6 \mathrm{ml}$ of reaction mix ( $0.1 \mathrm{M}$ sodium phosphate [pH 7.8], $10 \mathrm{mM} \mathrm{KCl}, 50 \mathrm{mM} \beta$-mercaptoethanol, $1 \mathrm{mM} \mathrm{MgCl}_{2}$ ). The reaction mix was warmed to $37^{\circ} \mathrm{C}$, and $120 \mu$ l of ortho-nitrophenol- $\beta$-D-galactopyranoside $(2 \mathrm{mg} / \mathrm{ml})$ was added and incubated at $37^{\circ} \mathrm{C}$. The reactions were allowed to proceed until a visible color developed and then were stopped by the addition of 0.3 $\mathrm{ml}$ of $\mathrm{Na}_{2} \mathrm{CO}_{3}$ and extrapolated to $\mathrm{A}_{420 / \mathrm{h}}$. Promoter activity was expressed as picomoles of chloramphenicol acetylated per milligram of cytoplasmic protein/h per $\mathrm{A}_{420 \mathrm{~h}}$

Western immunoblot analysis. Before analysis by Western blotting,

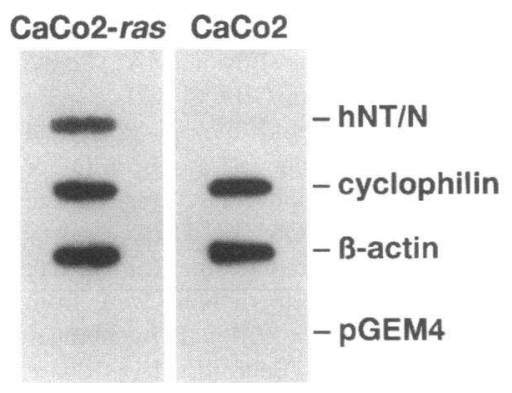

Figure 2. Nuclear run-on assay. $5 \mu \mathrm{g}$ of linearized cDNAs encoding human NT/N $(h N T / N)$, cyclophilin, and $\beta$-actin was blotted onto membranes and hybridized to radiolabeled RNA synthesized in nuclei isolated from $\mathrm{CaCo} 2-$ ras and $\mathrm{CaCo} 2$ cells. The pGEM4 plasmid was used to deter-

mine nonspecific background hybridization. A representative assay from two independent experiments is shown. After washing, the filters were exposed to Kodak XAR film using two intensifying screens at $-70^{\circ} \mathrm{C}$ for $24 \mathrm{~h}$ 
A

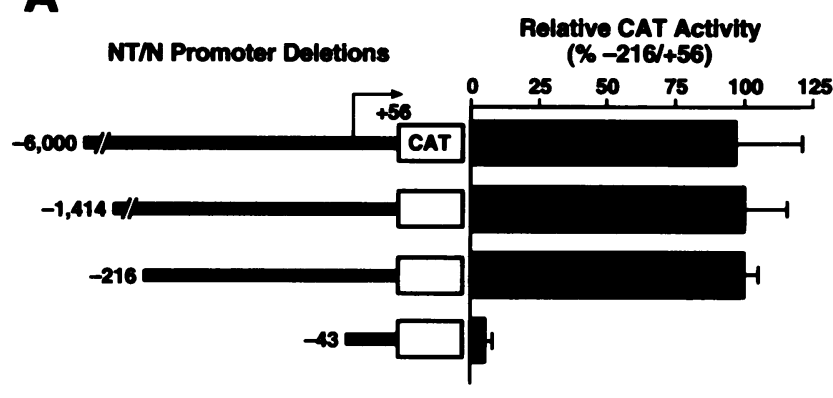

B

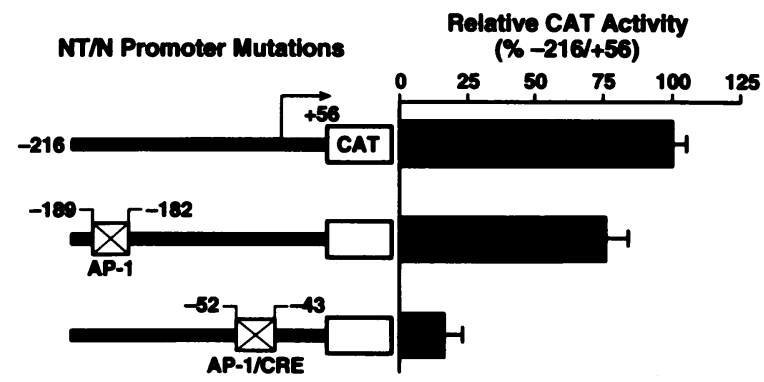

Figure 3. Transient transfection assays. (A) NT/N promoter-CAT 5' deletions transiently transfected in $\mathrm{CaCo}$-ras cells. CAT activity (mean \pm SD) for four independent transfections is expressed relative to the activity of -216 after normalizing for differences in transfection efficiency by the $\beta$-galactosidase plasmid (pCH110). (B) NT/N promoter mutations $(-189 /-182$ and $-52 /-43)$ transfected in CaCo2-ras. CAT activity (mean $\pm \mathrm{SD}$ ) for four independent transfections is expressed relative to the wild-type $(-216 /+56)$ NT/N promoter construct.

protein samples were resolved by sodium dodecyl sulfate (SDS)-12\% PAGE and electroblotted onto Immobilon P membranes. Filters were incubated overnight at room temperature in blocking solution (Trisbuffered saline containing $5 \%$ nonfat dried milk and $0.05 \%$ Tween 20 ), followed by a 4-h incubation with the rat anti-Ras monoclonal antibody (1:300 dilution). Filters were washed three times and incubated with a horseradish peroxidase-conjugated goat anti-rat immunoglobulin as a secondary antibody (1:1,000 dilution) for $1 \mathrm{~h}$. After three final washes, the immune complexes were visualized using enhanced chemiluminescence detection.

\section{Results}

$N T / N$ is expressed in the Ras-transformed $\mathrm{CaCo} 2$ cell line. Stable transfection of the v-Ha-ras oncogene induces morphologic differentiation of the human colon cancer cell line $\mathrm{CaCo} 2$ into a small bowel-like phenotype (24). We first determined by a sensitive RNase protection analysis whether the CaCo2-ras cell line expressed the gene for human NT/N, a small bowelassociated endocrine product (Fig. $1 \mathrm{~A}$ ). As a positive control, RNA from the human endocrine cell line BON, which is known to constitutively express the NT/N gene (44), was used and, as expected, demonstrated a 180 -base protection product consistent with exon 1 of the human NT/N gene. In addition, NT/N expression was identified in CaCo2-ras (lanes 1 and 2; Fig. 1 $A$ ). In contrast, the RNA samples from subconfluent cultures of parental $\mathrm{CaCo} 2$ cells demonstrated only minimal expression of NT/N (lanes 3 and 4; Fig. $1 A$ ).

To confirm that NT/N transcripts of the correct size were expressed, Northern blot hybridization was performed (Fig. 1 $B$ ). Consistent with previous reports of NT/N expression in the
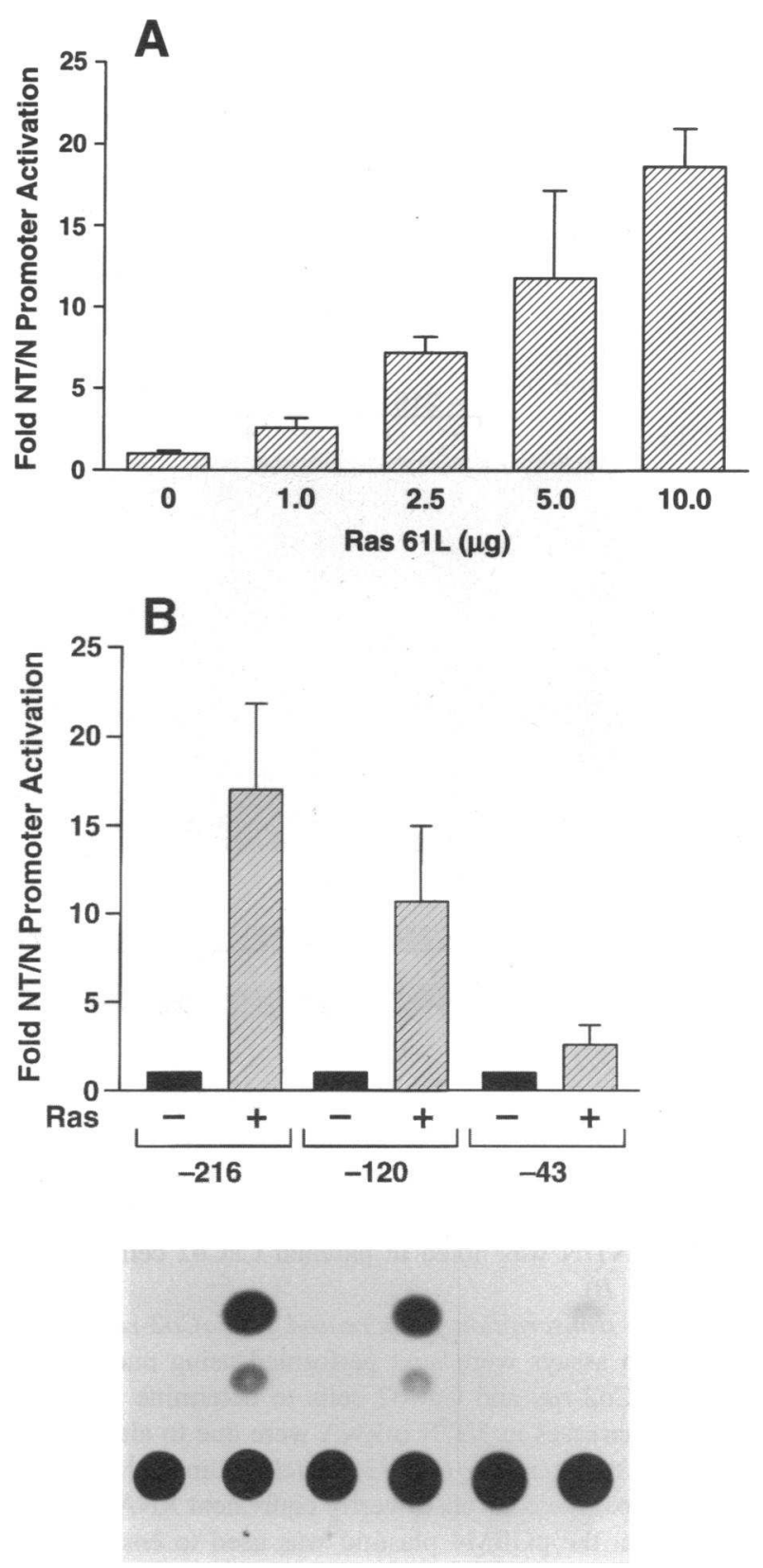

Figure 4. Cotransfection of oncogenic Ras expression vector with wildtype NT/N-CAT. (A) Cotransfection of oncogenic Ras expression vector (61L) with $15 \mu \mathrm{g} \mathrm{NT/N-CAT}(-216 /+56)$ and $5 \mu \mathrm{g}$ pCH1 10 in parental $\mathrm{CaCo} 2$ cells. Amount of DNA was kept constant in each transfection with vector DNA (pGEM4). Data are expressed as the fold mean \pm SD of the fold for three transfections. (B) NT/N-CAT deletion constructs $(15 \mu \mathrm{g})$ cotransfected with Ras expression vector $61 \mathrm{~L}(10 \mu \mathrm{g})(\mathrm{V})$. NT/ $\mathrm{N}$ promoter activity is expressed as mean fold activation ( $\pm \mathrm{SD}$ ) compared with NT/N-CAT without $61 \mathrm{~L}(\square)$ for at least four transfections. A representative CAT assay is shown. (C) Representative RNase protection analysis of $5 \mu \mathrm{g}$ poly(A) ${ }^{+}$RNA from $\mathrm{CaCo} 2$ cells transiently transfected with either NT/N-CAT deletion constructs alone or with 61L; DNA was maintained constant with pGEM4 vector DNA. In addition $\mathrm{CaCo} 2$ cells were mock transfected and RNA was analyzed. The RNA probe (pG4-20) used in this analysis is depicted in the schematic diagram. Probe alone is $\sim 364$ bases; probe hybridized with RNA samples expressing the rat NT/N-CAT hybrid gene protects a 312-base product. To ensure intact RNA samples, a separate RNase protection assay was performed using human GAPDH or a probe. $M 1$, RNA molecular size marker (Ambion). $M 2,{ }^{32} \mathrm{P}$-labeled HinfI-digested $\phi$ X174 DNA fragments (Promega) (sizes on the left in bases). 

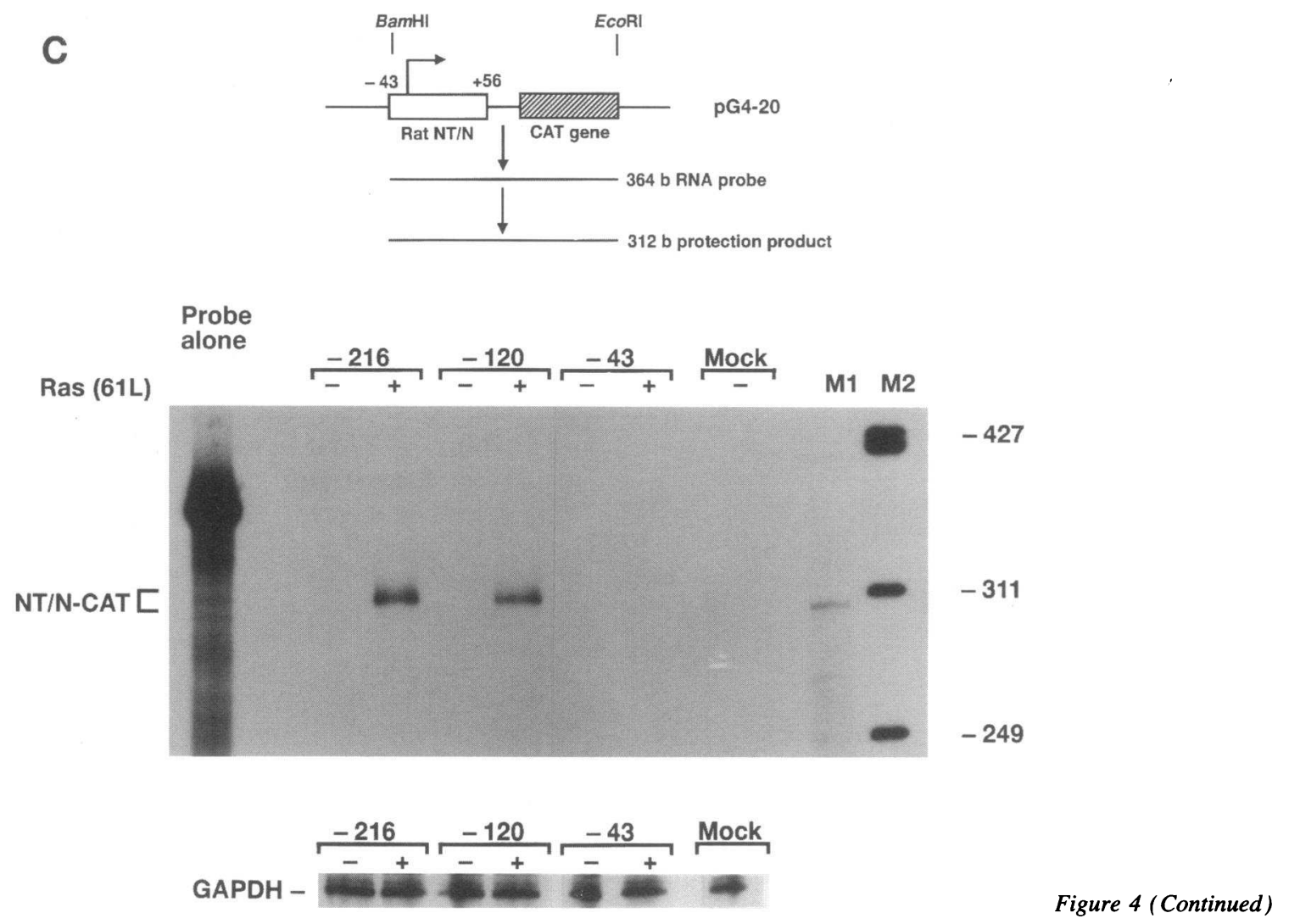

human small bowel $(37,39), \mathrm{CaCo} 2$-ras cells express mRNAs of 1.0 - and $1.5-\mathrm{kb}$ sizes with the smaller $1.0-\mathrm{kb}$ species slightly more abundant than the 1.5-kb mRNA (lanes 1 and 2; Fig. 1 $B)$. Similar to the findings by RNase protection, minimal to no expression of $\mathrm{NT} / \mathrm{N}$ was noted in parental $\mathrm{CaCo} 2$ cells (lanes 3 and 4 ; Fig. $1 B$ ).

NT/N gene transcription is increased in CaCo2-ras cells. Nuclear run-on assays were next performed using nuclei isolated from $\mathrm{CaCo} 2-$ ras and $\mathrm{CaCo} 2$ cells to determine whether the dramatic increases in NT/N mRNA were due to alterations in the rate of transcription (Fig. 2). Cyclophilin and $\beta$-actin were used as positive controls to verify equivalent RNA inputs, and in addition, the pGEM4 plasmid was used to ensure that the signals did not reflect nonspecific hybridization to probe sequences. We found that the apparent rate of transcription of human NT/N was $\sim 10$-fold higher in $\mathrm{CaCo} 2$-ras than in $\mathrm{CaCo} 2$ cells when quantitated by densitometry and normalized to the cyclophilin signal for each preparation. The results of these experiments clearly demonstrate an increase in the relative rate of NT/N gene transcription in the Ras-transformed $\mathrm{CaCo} 2$ cell line compared with parental $\mathrm{CaCo} 2$ cells, suggesting that induction of the NT/N gene is mediated primarily at the transcriptional level. Furthermore, this induction appears specific since neither $\beta$-actin nor cyclophilin gene transcription was increased in the CaCo2-ras cell line.

A proximal AP-1/CRE promoter element is crucial for Rasmediated NT/N activation. Ras-mediated activation of NT/N may occur as a result of activation of certain transcription factors (e.g., the AP-1 protein c-Jun), which then bind to specific promoter elements of the target gene (10-15). Contained within the upstream 200 nucleotides of the NT/N promoter are several important DNA regulatory regions known to be important for induction of NT/N expression in PC12 cells (49). These include a distal consensus AP-1 site (TGAGTCA) and a proximal nearconsensus AP-1/CRE site (TGACATCA), which is identical to a c-jun autoregulatory element (58). To define the cis-elements of the NT/N promoter that are responsible for Ras-mediated activation, transient transfection assays were performed using NT/N 5'-deletion constructs linked to the CAT reporter gene (Fig. $3 \mathrm{~A}$ ). Deletion of nucleotides between -6000 and -216 produced no decrease in CAT activity; however, deletion from -216 to -43 , a minimal promoter plasmid in which the proximal AP-1/CRE element located at -48 to -41 is truncated but still retains the NT/N TATA box, silenced the NT/N promoter when transiently transfected into $\mathrm{CaCo}$-ras cells.

To better delineate the sequences within these 216 nucleotides that are required for ras activation, linker scanning mutations of the distal consensus AP-1 site, located at -188 to -182 , and the proximal $\mathrm{AP}-1 / \mathrm{CRE}$ site were transfected into $\mathrm{CaCo}$ ras cells (Fig. $3 \mathrm{~B}$ ). Mutation of the distal AP-1 site produced only a $25 \%$ decrease in CAT activity; however, alteration of the proximal AP-1/CRE promoter element decreased CAT activity $>80 \%$. Taken together, these findings demonstrate that the upstream 216 base pairs of the NT/N promoter are required for Ras-mediated activation and that a proximal AP-1/CRE promoter element appears crucial for this activation.

Oncogenic Ha-ras stimulates NT/N promoter activation in transient cotransfection assays. Expression of NT/N in the stably transfected $\mathrm{CaCo} 2-$ ras cell line suggested that ras can stimulate the activity of NT/N; however, it is possible that the stimulating effect on the NT/N enhancer in these cells may be secondary to genetic changes as a result of the differentiation process. To test directly whether Ha-ras can stimulate NT/N activity, we used an expression construct $(61 \mathrm{~L})(50,51)$ that contains the strongly transforming Ha-ras variant cotransfected with the wild-type $(-216 /+56)$ NT/N-CAT vector. Increasing amounts 
of $61 \mathrm{~L}$ resulted in dose-dependent increases in NT/N promoter activation (Fig. $4 \mathrm{~A}$ ). To further confirm the importance of the proximal NT/N promoter sequences, NT/N deletion constructs of $-216,-120$, and -43 were cotransfected with ras expression vector $61 \mathrm{~L}$ (Fig. $4 \mathrm{~B}$ ). A 17 -fold increase in NT/N promoter activity was noted using the $-216 \mathrm{NT} / \mathrm{N}$ promoter construct. Deletion to -120 , which removes the distal AP-1 site, reduced NT/N activation by only $25 \%$. On the other hand, cotransfection of activated Ras with the truncated -43 NT/N-CAT plasmid produced only a minimal (twofold) increase in NT/N promoter activity compared with control plates not transfected with 61L.

To verify that expression of the CAT gene in the fusion plasmids was under the control of the NT/N promoter, so that the CAT-specific mRNAs were initiated at the authentic NT/N CAP site, RNase protection analyses were performed (Fig. 4 C). $\mathrm{CaCo} 2$ cells transfected with the $5^{\prime}$-deletion fusion genes were analyzed using an RNA probe (pG4-20) to detect hybrid rat NT/N-CAT mRNA (schematic diagram of probe shown at top of Fig. $4 \mathrm{C}$ ). The size of the protected fragments $(\sim 312$ bases) confirmed that transcription begins at the bona fide rat NT/N transcriptional start site and, in addition, that the changes in CAT activity resulting from progressive deletion of the NT/ $\mathrm{N}$ promoter closely parallel changes in mRNA levels. Furthermore, intact RNA samples were confirmed by hybridization with GAPDH and analysis by RNase protection. Collectively, these results, obtained by transient transfection assays, further support the findings of Ras-mediated activation of NT/N and the importance of the proximal NT/N promoter for this activation.

$N T / N$ promoter activity is increased by overexpression of normal c-Ha-ras, and this induction is blocked by a dominantnegative Raf. Thus far, we have shown that activated Ras, either stably or transiently transfected into $\mathrm{CaCo} 2$ cells, stimulates NT/N expression. This does not establish, however, whether normal (wild-type) Ras increases NT/N gene expression. To directly assess this possibility, transfection studies using increasing amounts of a plasmid encoding WT-Ras and a constant amount of NT/N-CAT $(-216 /+56)$ were performed in $\mathrm{CaCo} 2$ cells. Cotransfection of WT-Ras resulted in a dose-dependent increase of $\mathrm{NT} / \mathrm{N}$ promoter activity with a 4.5 -fold increase noted using $10 \mu \mathrm{g}$ of wild-type (WT)-Ras (Fig. $5 A$ ). These increases were relatively modest compared with the 17 -fold increase in promoter activity associated with overexpression of oncogenic Ras; however, they provide further support of a role for Ras in the downstream activation of the NT/N gene in the differentiated small bowel.

Next, to ascertain whether Raf kinase lies downstream of Ras, cotransfection studies were performed with Raf constructs that encode a dominant-negative Raf (Raf-C4) and, as a control, a mutant of this dominant-negative Raf that is no longer inhibitory (Raf-C4pm17) (Fig. 5 B). Dominant-negative Raf blocked the induction of the NT/N promoter by WT-Ras in a dosedependent manner, whereas the inactive version of the dominant-negative Raf had no significant effect on the Ras-mediated stimulation of the NT/N promoter. Taken together, these findings indicate that normal Ras can also stimulate NT/N promoter activity, albeit at lower levels than oncogenic Ras. Furthermore, inhibition of this NT/N promoter activation was observed using a dominant-negative Raf, suggesting that Raf lies downstream of Ras in the signaling pathway that culminates eventually in NT/N gene induction.

Concomitant increases of NT/N mRNA and $p 21^{\text {ras }}$ protein in postconfluent cultures of $\mathrm{CaCo}$. Because $\mathrm{CaCo} 2$ cells can differentiate spontaneously to a small bowel phenotype when
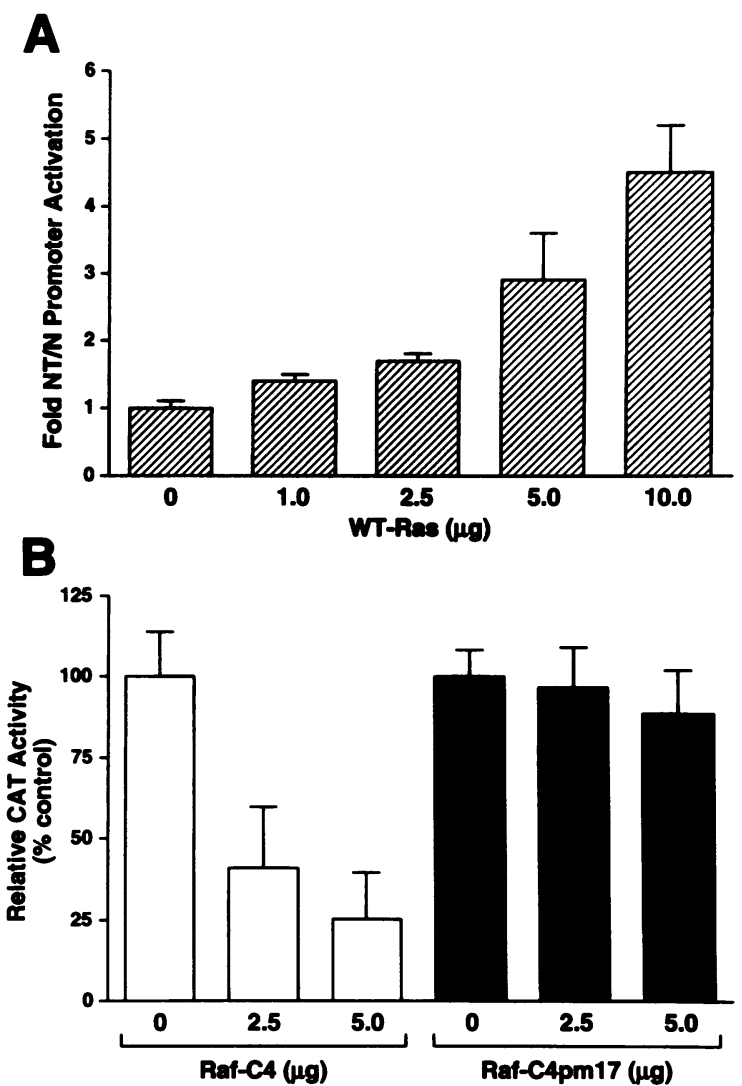

Figure 5. Cotransfection of wild-type (WT)-Ras with NT/N-CAT. (A) Cotransfection of WT-Ras expression vector with $15 \mu \mathrm{g} \mathrm{NT/N-CAT}$ $(-216 /+56)$ and $5 \mu \mathrm{g} \mathrm{pCH} 110$ in parental $\mathrm{CaCo} 2$ cells. Amount of DNA was kept constant in each transfection with vector DNA (pGEM4). Data are expressed as the fold mean \pm SD of the fold for four to six transfections. $(B)$ Dominant-negative Raf inhibits WT-Ras induction of the NT/N promoter in a dose-dependent fashion. $\mathrm{CaCo} 2$ cells were cotransfected with NT/N-CAT (15 $\mu \mathrm{g})$, pCH110 (5 $\mu \mathrm{g})$, WT-Ras (10 $\mu \mathrm{g}$ ), and increasing amounts of either the dominant-negative Raf-C4 expression vector $(\square)$ or a vector, Raf-C4pm17, encoding an inactivated form of the dominant-negative form ( $\square)$. CAT activity (mean $\pm S D$ ) for four transfections is expressed relative to control (WT-Ras alone).

they reach a postconfluent state (59-62), we next determined whether NT/N was expressed in postconfluent cultures of $\mathrm{CaCo} 2$ and, similarly, whether Ras protein was increased in a concomitant fashion. $\mathrm{CaCo} 2$ cells were harvested at 3, 6, 12, and $15 \mathrm{~d}$ after reaching $100 \%$ confluency. RNase protection studies identified increased expression of NT/N by postconfluent day 6 (Fig. $6 \mathrm{~A}$ ). Parallel dishes of $\mathrm{CaCo} 2$ cells were extracted for protein and analyzed by Western blot for expression of $\mathrm{p} 21^{\text {ras }}$ using an anti-Ras antibody that detects antigenic determinants common to all three members of the ras gene family. Similar to NT/N gene expression, increases of $\mathrm{p} 21^{\text {ras }}$ were noted by $6 \mathrm{~d}$ postconfluency (Fig. $6 \mathrm{~B}$ ). Collectively, these studies suggest an important role for the endogenous Ras signaling pathway in the expression of NT/N in the gut-derived $\mathrm{CaCo} 2$ cell line that spontaneously differentiates to a small bowel phenotype under the appropriate culture conditions.

\section{Discussion}

Despite intensive efforts, the molecular mechanisms leading to gut differentiation and the expression of terminally differenti- 

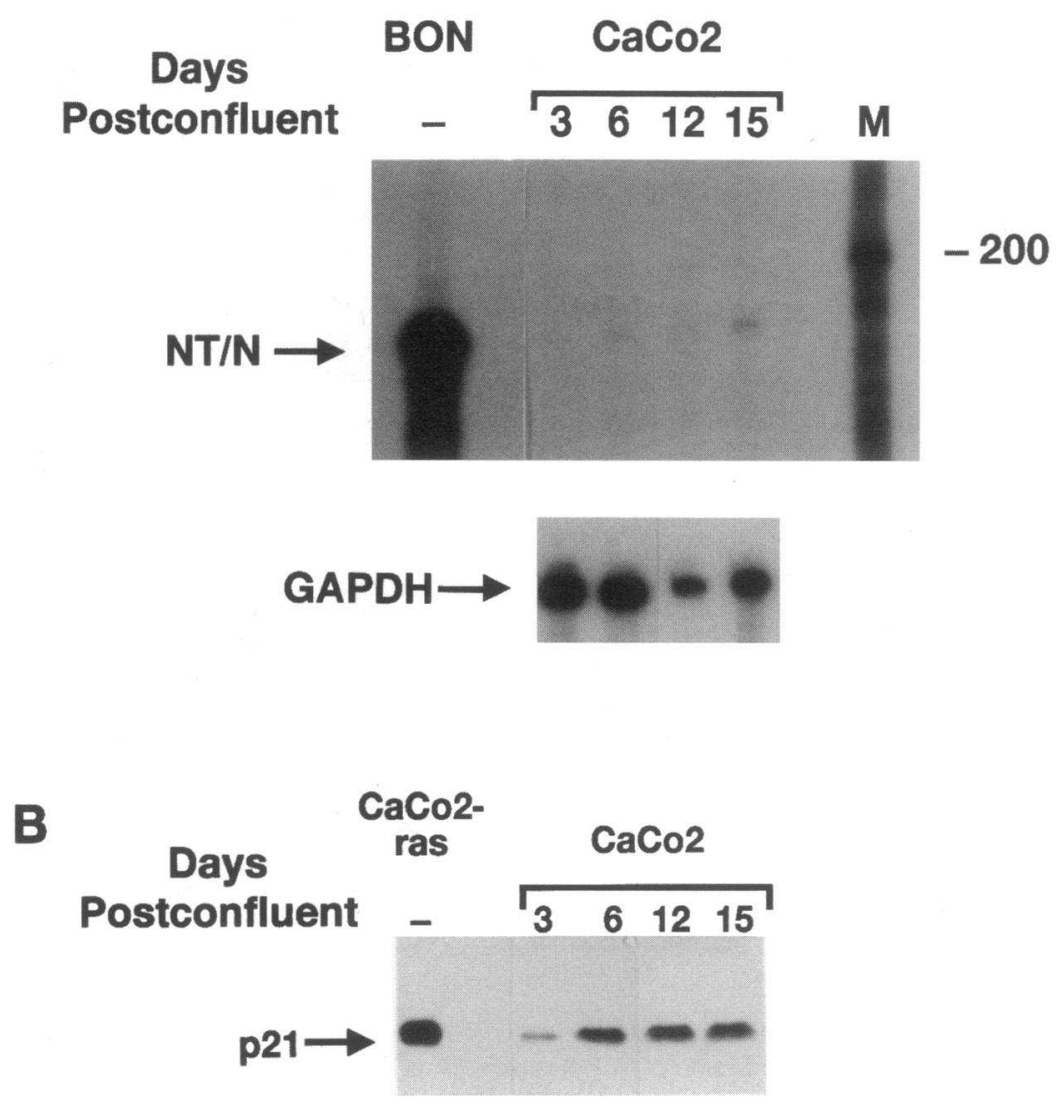

Figure 6. Analysis of NT/N gene expression and $\mathrm{p} 21^{\text {ras }}$ in postconfluent $\mathrm{CaCo} 2$ cells. $(A)$ RNase protection analysis of $\mathrm{CaCo} 2$ cell poly[A $]^{+}$RNA $(10 \mu \mathrm{g})$ at 3,6 , 12 , and $15 \mathrm{~d}$ postconfluency hybridized with human NT/ $\mathrm{N}$ cRNA probe(pHNT EO.9). BON cell RNA $(2.5 \mu \mathrm{g})$ was used as a positive control to ensure intact RNA samples, and a separate RNase protection assay was performed using human GAPDH as a probe. $M$, RNA molecular weight marker (Ambion). (B) Western blot analysis of $\mathrm{CaCo} 2$ protein lysate $(125 \mu \mathrm{g})$ at $3,6,12$, and $15 \mathrm{~d}$ postconfluency using rat anti-ras antibody (Santa Cruz). CaCo2-ras protein $(50 \mu \mathrm{g})$ was used as a positive control. ated products (e.g., gut hormones) remain poorly defined. The ras gene family has been implicated in the malignant transformation of a variety of cell types including colonic mucosa (1, 3,16 ); however, recent studies also suggest an important role for cellular Ras in the differentiation and development of normal tissues. For example, a gradient of p2 ${ }^{\text {ras }}$ expression is demonstrated in the mucosa of the GI tract with increasing levels noted in the more differentiated cells of the small bowel (25). Consistent with these findings, Celano et al. (24) demonstrated recently that stable transfection of the Ha-ras oncogene into the human colon cancer line $\mathrm{CaCo} 2$ induces a differentiated pattern characterized by a decreased proliferative capacity and the induction of gene expression of a number of markers of small bowel differentiation. $\mathrm{CaCo} 2$ cells have the unique property of spontaneous differentiation to a small bowel-like phenotype in culture with microvilli, dome formation, and maximal expression of sucrase-isomaltase and alkaline phosphatase noted 4-6 $\mathrm{d}$ after the cells have reached confluency (59-62). These findings indicate that the parental $\mathrm{CaCo} 2$ and $\mathrm{CaCo} 2-$ ras cell lines offer a unique and well-characterized system to further define the cellular mechanisms leading to small bowel differentiation and the regulation of expression of differentiated cellular products of the GI tract, such as the gut hormones, in which little is known about the molecular factors mediating the distinct patterns of cell-specific expression.

Expression of the NT/N gene is regulated in a temporaland spatial-specific pattern and is highly dependent on the state of gut differentiation $(37,38)$. For example, NT/N expression is limited in the adult GI tract to the small bowel; however,
$\mathrm{NT} / \mathrm{N}$ is expressed in the fetal colon during midgestation when the colon morphologically resembles the small bowel (37). NT/ $\mathrm{N}$ is not expressed in the normal colon of the newborn or the adult. In this study, we have shown that the NT/N gene is expressed in the gut-derived $\mathrm{CaCo} 2$ cell line that has been stably transfected with the Ha-ras oncogene. Furthermore, our results clearly indicate that the Ras-mediated induction of NT/N mRNA transcripts is primarily due to an increase in the rate of gene transcription.

Oncogenic ras enhances transcription of certain target genes by activation of various transcription factors $(10,11)$. For example, in several cell systems Ras stimulates the transcriptional activity of the AP-1 protein C-Jun by hyperphosphorylation of serines 63 and 73 located in its transcription-activating domain (13-15). This, in turn, leads to the activation of certain target genes containing AP-1 sites that are capable of binding c-Jun $(10,11)$. Ha-ras is also known to stimulate activity of another AP-1 protein, c-Fos; however, induction of c-Fos by Ras is transient and there is no evidence for elevated c-Fos expression in most transformed cells (13). Contained within the proximal 200 nucleotides of the rat NT/N promoter is a distal consensus AP-1 site (TGAGTCA) located at -188 to -182 and a proximal AP-1/CRE motif (TGACATCA) (49). This proximal AP-1/CRE site is identical to a c-jun autoregulatory element capable of binding both AP-1 and CREB/ATF factors $(58,63)$. In preliminary studies, using the endocrine cell line BON that constitutively expresses the NT/N gene, we have found that the distal AP-1 site binds JunD, c-Fos, and Fra-1 proteins, whereas the proximal element of the NT/N promoter binds c-Jun, JunD, 
CREB, activating transcription factor-1 (ATF-1), and ATF-2 proteins (Evers, B. M., unpublished results). In our study, we performed functional promoter analyses to define the elements of the NT/N promoter that are responsible for Ras-mediated activation. Deletion studies identify the 216 base pairs immediately upstream of the NT/N transcriptional start site as essential for Ras-mediated activation in $\mathrm{CaCo} 2$ cells. Moreover, mutations that specifically alter the two promoter elements identify the proximal promoter element as critical for Ras activation of $\mathrm{NT} / \mathrm{N}$ in CaCo2-ras cells. Taken together, these findings suggest that Ras activation of NT/N is probably mediated by an enhanced potency of c-Jun with only minimal contribution by cFos. Alternatively, another possibility is that Ras mediates NT/ $\mathrm{N}$ induction through activation of one of the ATFs, which bind to this multifunctional proximal promoter element. Support of this possibility is provided by a recent report demonstrating Ras-mediated induction of a prostaglandin synthase gene via a proximal ATF/CRE response element (64).

In addition to the NT/N gene induction noted with activated Ras, we also show that transfection of a plasmid encoding wildtype Ras into $\mathrm{CaCo} 2$ cells induces NT/N promoter activity, albeit at lower levels than oncogenic Ras. This induction was inhibited, in a dose-dependent fashion, by a dominant-negative Raf kinase. These findings suggest a role for cellular Ras in the increased expression of the NT/N gene in gut-derived $\mathrm{CaCo} 2$ cells. Further evidence to support this speculation is provided by the finding of increased NT/N expression in postconfluent cultures of parental $\mathrm{CaCo} 2$ cells that is associated with concomitant increases of p21 ras protein. Collectively, our results imply a functional requirement for the Ras signaling pathway in the activation of NT/N, a cell-specific endocrine product of the gut.

Consistent with our findings of Ras-mediated increases of NT/N expression, Ras overexpression results in the high-level expression of the peptide hormone calcitonin in a small cell lung cancer cell line (DMS 53) (65) and a medullary thyroid cancer line (MTC) (21). Furthermore, Conrad et al. (66) recently reported that components of the Ras pathway are required for the regulation of neuroendocrine cell-specific genes in the pituitary gland. Therefore, our findings, as well as those of others $(21,65,66)$, indicate that genes (such as NT/N) expressed in a very strict tissue-specific manner may be subject to Ras regulation.

The results presented in this study indicate that expression of the NT/N gene and NT/N promoter fusion gene constructs is stimulated by $\mathrm{p} 21^{\text {ras }}$ expression in human $\mathrm{CaCo} 2$ cells that differentiate to a small bowel phenotype. This effect on NT/N is mediated by increases in gene transcription and, in large part, through a palindromic element in the proximal NT/N promoter. Stimulation of NT/N expression is observed both for a stably integrated ras gene and for transiently transfected activated and wild-type ras expression plasmids. These findings are of novel interest in understanding both general mechanisms of promoter responsiveness to Ras and the specific cellular factors regulating differentiated gene expression in the gut. Although previous reports have shown that activated forms of Ras can stimulate neuroendocrine gene expression in various cell lines $(21,65)$, ours is one of the first studies documenting that these signaling pathways affect a cellular gene that is normally expressed only in highly differentiated cells of the gut mucosa. Our data also underscore the possibility that tissue-specific genes expressed in highly differentiated and distinct cells of the gut may be subject to Ras regulation and, moreover, Ras may be actively involved in gene regulation during normal gut development and differentiation.

\section{Acknowledgments}

The authors acknowledge the generous receipt of various plasmids for use in our studies: Dr. Channing J. Der for pZIPneoRas(61L) and pZIPneoRas(WT); Dr. Ulf Rapp for the dominant-negative Raf (Raf-C4) and the control mutant (Raf-C4pm17), which is no longer inhibitory; and Dr. Paul Dobner for NT/N-CAT promoter constructs. We also thank Dr. Dobner for his helpful suggestions throughout the course of this work and Larry Janecka, Steve Schuenke, Eileen Figueroa, and Bob Todd for manuscript preparation.

This study was supported by grants AG-10885 and DK-35608 from the National Institutes of Health, grant 15867 from the Shriners Burns Institute, and the James E. Thompson Memorial Fund.

\section{References}

1. Lowy, D. R., and B. M. Willumsen. 1993. Function and regulation of RAS. Annu. Rev. Biochem. 62:851-891.

2. Satoh, T., M. Nakafuku, and Y. Kaziro. 1992. Function of ras as a molecular switch in signal transduction. J. Biol. Chem. 267:24149-24152.

3. Barbacid, M. 1987. ras Genes. Annu. Rev. Biochem. 56:779-827.

4. Nishida, E., and Y. Gotoh. 1993. The MAP kinases cascade is essential for diverse signal transduction pathways. Trends Biochem. Sci. 18:128-131.

5. Schlessinger, J. 1993. How receptor tyrosine kinases activate ras. Trends Biochem. Sci. 18:273-275.

6. Blenis, J. 1993. Signal transduction via the MAP kinases: proceed at your own RSK. Proc. Natl. Acad. Sci. USA. 90:5889-5892.

7. Pelech, S. L., and J. S. Sanghera. 1992. MAP kinases: charting the regulatory pathways. Science (Wash. DC). 257:1355-1356.

8. Koide, H., T. Satoh, M. Nakafuku, and Y. Kaziro. 1993. GTP-dependent association of Raf-1 with Ha-ras: identification of Raf as a target downstream of Ras in mammalian cells. Proc. Natl. Acad. Sci. USA. 90:8683-8686.

9. Hall, A. 1994. A biochemical function for ras-at last. Science (Wash. DC). 264:1413-1414.

10. Gutman, A., and B. Wasylyk. 1991. Nuclear targets for transcription regulation by oncogenes. Trends Genet. 7:49-54.

11. Angel, P., and M. Karin. 1991. The role of Jun, Fos and the AP-1 complex in cell-proliferation and transformation. Biochem. Biophys. Acta. 1072:129-157.

12. Karin, M. 1992. Signal transduction from cell surface to nucleus in development and disease. FASEB (Fed. Am. Soc. Exp. Biol.) J. 6:2581-2590.

13. Binétruy, B., T. Smeal, and M. Karin. 1991. Ha-Ras augments c-Jun activity and stimulates phosphorylation of its activation domain. Nature (Lond.). 351:122-127.

14. Smeal, T., B. Binetruy, D. A. Mercola, M. Birrer, and M. Karin. 1991. Oncogenic and transcriptional cooperation with Ha-Ras requires phosphorylation of c-Jun on serines 63 and 73. Nature (Lond.). 354:494-496.

15. Smeal, T., B. Binetruy, D. Mercola, A. Grover-Bardwick, G. Heidecker, U. R. Rapp, and M. Karin. 1992. Oncoprotein-mediated signalling cascade stimulates c-Jun activity by phosphorylation of serines 63 and 73. Mol. Cell. Biol. 12:3507-3513.

16. Bos, J. L. 1988. The ras gene family and human carcinogenesis. Mutat. Res. 195:255-271

17. Noda, M., M. Ko, A. Ogura, D. Liu, T. Amano, T. Takano, and Y. Ikawa. 1985. Sarcoma viruses carrying ras oncogenes induce differentiation-associated properties in a neuronal cell line. Nature (Lond.). 318:73-75.

18. Bar-Sagi, D., and J. R. Feramisco. 1985. Microinjection of the ras oncogene protein into PC12 cells induces morphological differentiation. Cell. 42:841848.

19. Szeberényi, J., H. Cai, and G. M. Cooper. 1990. Effect of a dominant inhibitory ha-ras mutation on neuronal differentiation of PC12 cells. Mol. Cell. Biol. 10:5324-5332.

20. Sassone-Corsi, P., C. J. Der, and I. M. Verma. 1989. ras-Induced neuronal differentiation of PC12 cells: possible involvement of fos and jun. Mol. Cell. Biol. 9:3174-3183.

21. Nakagawa, T., M. Mabry, A. de Bustros, J. N. Ihle, B. D. Nelkin, and S. B. Baylin. 1987. Introduction of v-Ha-ras oncogene induces differentiation of cultured human medullary thyroid carcinoma cells. Proc. Natl. Acad. Sci. USA. 84:5923-5927.

22. Benito, M., A. Porras, A. R. Nebreda, and E. Santos. 1991. Differentiation of 3T3-L1 fibroblasts to adipocytes induced by transfection of ras oncogenes. Science (Wash. DC). 253:565-568.

23. Thorburn, A., J. Thorburn, S.-Y. Chen, S. Powers, H. E. Shubeita, J. R. Feramisco, and K. R. Chien. 1993. HRas-dependent pathways can activate 
morphological and genetic markers of cardiac muscle cell hypertrophy. J. Biol. Chem. 268:2244-2249.

24. Celano, P., C. M. Berchtold, M. Mabry, M. Carroll, D. Sidransky, R. A. Casero, Jr., and R. Lupu. 1993. Induction of markers of normal differentiation in human colon carcinoma cells by v-ras ${ }^{H}$ oncogene. Cell Growth \& Differ. 4:341347.

25. Furth, M. E., T. H. Aldrich, and C. Cordon-Cardo. 1987. Expression of ras proto-oncogene proteins in normal human tissues. Oncogene. 1:47-58.

26. Reinecke, M. 1985. Neurotensin. Immunohistochemical localization in central and peripheral nervous system and in endocrine cells and its functional role as neurotransmitter and endocrine hormone. Prog. Histochem. Cytochem. 16:1-172.

27. Armstrong, M. J., M. C. Parker, C. F. Ferris, and S. E. Leeman. 1986. Neurotensin stimulates $\left[{ }^{3} \mathrm{H}\right]$ oleic acid translocation across rat small intestine. Am. J. Physiol. 251(Gastrointest. Liver Physiol. 14):G823-G829.

28. Baca, I., G. E. Feurle, A. Schwab, U. Mittmann, W. Knauf, and T. Lehnert. 1982. Effect of neurotensin on exocrine pancreatic secretion in dogs. Digestion. 23:174-183.

29. Anderson, S., S. Rosell, U. Hjelmquist, D. Chang, and K. Folkers. 1977. Inhibition of gastric and intestinal motor activity in dogs by $\left(g \ln ^{4}\right)$ neurotensin. Acta Physiol. Scand. 100:231-235.

30. Thor, K., and S. Rosell. 1986. Neurotensin increases colonic motility. Gastroenterology. 90:27-31.

31. Chung, D. H., B. M. Evers, I. Shimoda, C. M. Townsend, Jr., S. Rajaraman, and J. C. Thompson. 1992. Effect of neurotensin on gut mucosal growth in jejunum and ileal thiry-villa fistulas. Gastroenterology. 103:1254-1259.

32. Evers, B. M., M. Izukura, D. H. Chung, D. Parekh, K. Yoshinaga, G. H. Greeley, Jr., T. Uchida, C. M. Townsend, Jr., and J. C. Thompson. 1992. Neurotensin stimulates growth of colonic mucosa in young and aged rats. Gastroenterology. 103:86-91.

33. Evers, B. M. M. Izukura, C. M. Townsend, Jr., T. Uchida, and J. C Thompson. 1992. Neurotensin prevents intestinal mucosal hypoplasia in rats fed an elemental diet. Dig. Dis. Sci. 37:426-431.

34. Feurle, G. E., B. Muller, and E. Rix. 1987. Neurotensin induces hyperplasia of the pancreas and growth of the gastric antrum in rats. Gut. 28(Suppl. S1):1923.

35. Wood, J. G., H. D. Hoang, L. J. Bussjaeger, and T. E. Solomon. 1988. Neurotensin stimulates growth of small intestine in rats. Am. J. Physiol. 255(Gas trointest. Liver Physiol. 18):G813-G817.

36. Evers, B. M., M. Izukura, S. Rajaraman, D. Parekh, K. Thakore, K Yoshinaga, T. Uchida, C. M. Townsend, Jr., and J. C. Thompson. 1994. Effect of aging on neurotensin-stimulated growth of rat small intestine. Am. J. Physiol. 267(Gastrointest. Liver Physiol. 30):G180-G186.

37. Evers, B. M., S. Rajaraman, D. H. Chung, C. M. Townsend, Jr., X. Wang, K. Graves, and J. C. Thompson. 1993. Differential expression of the neurotensin gene in the developing rat and human gastrointestinal tract. Am. J. Physiol. 265(Gastrointest. Liver Physiol. 28):G482-G490.

38. Muraki, K., S. P. Mitra, P. R. Dobner, and R. E. Carraway. 1993. Enhanced expression of neurotensin/neuromedin N mRNA and products of NT/NMN precursor processing in neonatal rats. Peptides. 14:1095-1102.

39. Evers, B. M., J. A. Ehrenfried, X. Wang, C. M. Townsend, Jr., and J. C. Thompson. 1994. Temporal-specific and spatial-specific patterns of neurotensin gene expression in the small bowel. Am. J. Physiol. 267(Gastrointest. Liver Physiol. 30):G875-G882.

40. Bell, L., and L. Williams. 1982. A scanning and transmission electron microscopical study of the morphogenesis of human colonic villi. Anat. Embryol. 165:437-455.

41. Lacroix, B., M. Kedinger, P. Simon-Assmann, M. Rousset, A. Zweibaum, and K. Haffen. 1984. Developmental pattern of brush border enzymes in the human fetal colon. Correlation with some morphogenetic events. Early Hum. Dev. 9:95-103.

42. Schwab, M., K. Alitalo, H. E. Varmus, and J. M. Bishop. 1983. A cellula oncogene (c-Ki-ras) is amplified, overexpressed, and located within karyotypic abnormalities in mouse adrenocortical tumour cells. Nature (Lond.). 303:497501.

43. Bean, A. J., A. Dagerlind, T. Hökfelt, and P. R. Dobner. 1992. Cloning of human neurotensin/neuromedin $\mathbf{N}$ genomic sequences and expression in the ventral mesencephalon of schizophrenics and age/sex matched controls. Neuroscience. 50:259-268.
44. Evers, B. M., J. Ishizuka, C. M. Townsend, Jr., S. Rajaraman, and J. C. Thompson. 1991. Expression of neurotensin messenger RNA in a human carcinoid tumor. Ann. Surg. 214:448-455.

45. Evers, B. M., J. Ishizuka, D. H. Chung, C. M. Townsend, Jr., and J. C. Thompson. 1992. Neurotensin expression and release in human colon cancers. Ann. Surg. 216:423-431.

46. Greenberg, M. E., and E. G. Ziff. 1984. Stimulation of 3T3 cells induces transcription of the c-fos proto-oncogene. Nature (Lond.). 311:433-438.

47. Cleveland, D. W., M. A. Lopata, R. J. MacDonald, N. J. Cowan, W. J. Rutter, and M. W. Kirschner. 1980. Number and evolutionary conservation of $\alpha$ and $\beta$-tubulin and cytoplasmic $\beta$ - and gamma-actin genes using specific cloned cDNA probes. Cell. 20:95-105.

48. Danielson, P. E., S. Forss-Petter, M. A. Brow, L. Calavetta, J. Douglass, R. J. Milner, and J. G. Sutcliffe. 1988. p1B15: a cDNA clone of the rat mRNA encoding cyclophilin. DNA. 7:261-267.

49. Kislauskis, E., and P. R. Dobner. 1990. Mutually dependent response elements in the cis-regulatory region of the neurotensin/neuromedin $\mathrm{N}$ gene integrate environmental stimuli in PC12 cells. Neuron. 4:783-795.

50. Der, C. J., T. Finkel, and G. M. Cooper. 1986. Biological and biochemical properties of human ras $^{\mathrm{H}}$ genes mutated at codon 61. Cell. 44:167-176.

51. Der, C. J., B.-T. Pan, and G. M. Cooper. 1986. ras $^{\mathrm{H}}$ mutants deficient in GTP binding. Mol. Cell. Biol. 6:3291-3294.

52. Bruder, J. T., G. Heidecker, and U. R. Rapp. 1992. Serum-, TPA-, and Ras-induced expression from Ap-1/Ets-driven promoters requires Raf-1 kinase. Genes Dev. 6:545-556.

53. Sambrook, J., E. F. Fritsch, and T. Maniatis. 1989. Molecular Cloning: A Laboratory Manual. Cold Spring Harbor Laboratory, Cold Spring Harbor, NY. 3 vols.

54. Graham, F. L., and A. J. Van der Eb. 1973. A new technique for the assay of infectivity of human adenovirus 5 DNA. Virology. 52:456-467.

55. Gorman, C. M., L. F. Moffat, and B. H. Howard. 1982. Recombinan genomes which express chloramphenicol acetyltransferase in mammalian cells. Mol. Cell. Biol. 2:1044-1051.

56. Hall, C. V., P. E. Jacob, G. M. Ringold, and F. Lee. 1983. Expression and regulation of Escherichia coli lacZ gene fusions in mammalian cells. J. Mol. Appl. Genet. 2:101-109.

57. Bradford, M. M. 1976. A rapid and sensitive method for the quantitation of microgram quantities of protein utilizing the principle of protein-dye binding Anal. Biochem. 72:248-254.

58. Angel, P., K. Hatori, T. Smeal, and M. Karin. 1988. The jun protooncogene is positively autoregulated by its product, jun/AP-1. Cell. 55:875-885

59. Pinto, M., S. Robine-Leon, M.-D. Appay, M. Kedinger, N. Triadou, E. Dussaulx, B. Lacroix, P. Simon-Assmann, K. Haffen, J. Fogh, and A. Zweibaum 1983. Enterocyte-like differentiation and polarization of the human colon carcinoma cell line Caco-2 in culture. Biol. Cell. 47:323-330.

60. Rousset, M., M. Labruthe, M. Pinto, G. Chevalier, C. Rouyer-Fessard, E. Dussaulx, G. Trugnan, N. Boige, J.-L. Brun, and A. Zweibaum. 1985. Enterocytic differentiation and glucose utilization in the human colon tumor cell line Caco2: modulation by forskolin. J. Cell. Physiol. 123:377-385.

61. Chantret, I., A. Barbat, E. Dussaulx, M. G. Brattain, and A. Zweibaum 1988. Epithelial polarity, villin expression, and enterocytic differentiation of cultured human colon carcinoma cells: a survey of twenty cell lines. Cancer Res. 48:1936-1942.

62. Hauck, W., and C. P. Stanners. 1991. Control of carcinoembryonic antigen gene family expression in a differentiating colon carcinoma cell line, Caco-2. Cancer Res. 51:3526-3533.

63. Masquilier, D., and P. Sassone-Corsi. 1992. Transcriptional cross-talk: nuclear factors CREM and CREB bind to AP-1 sites and inhibit activation by Jun. J. Biol. Chem. 267:22460-22466.

64. Xie, W., B. S. Fletcher, R. D. Andersen, and H. R. Herschman. 1994. v$s r c$ Induction of the TIS10/PGS2 prostaglandin synthase gene is mediated by an ATF/CRE transcription response element. Mol. Cell. Biol. 14:6531-6539.

65. Mabry, M., T. Nakagawa, S. Baylin, O. Pettengill, G. Sorenson, and B. Nelkin. 1989. Insertion of the v-Ha-ras oncogene induces differentiation of calcitonin-producing human small cell lung cancer. J. Clin. Invest. 84:194-199.

66. Conrad, K. E., J. M. Oberwetter, R. Vaillancourt, G. L. Johnson, and A. Guittierrez-Hartmann. 1994. Identification of the functional components of the ras signaling pathway regulating pituitary cell-specific gene expression. Mol. Cell. Biol. 14:1553-1565. 